\title{
Afrikaans uit en van Europa: Deel een van die storie van Afrikaans
}

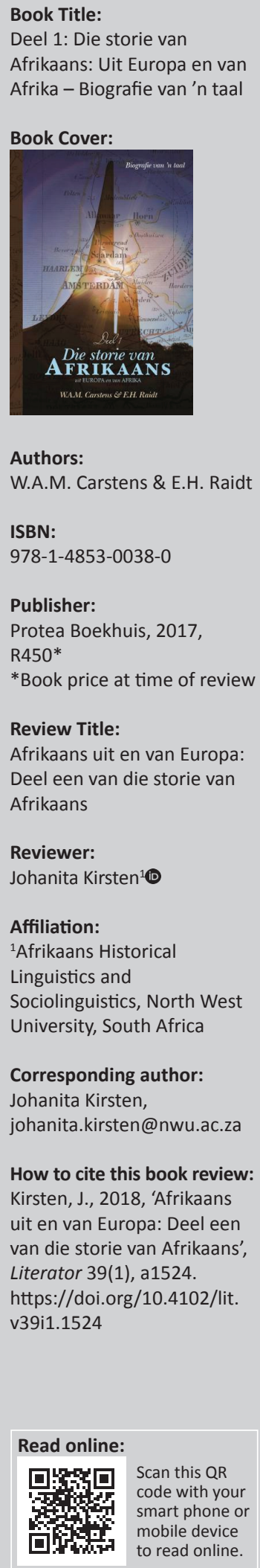

\section{Oorsig}

Hierdie boek is deel een van Die storie van Afrikaans, wat op Die Europese geskiedenis van Afrikaans fokus. Na die inleidende hoofstuk wat die konsep taal en die bestudering van taal oorweeg, gee hoofstuk twee 'n oorsig oor die ontwikkeling van die taalkunde, en ook kortliks aandag aan die datering van die oorspronklike ontwikkeling van taal. Hoofstuk drie handel oor die vraag na wat ' $n$ taal is en wat tale en dialekte onderskei, met 'n oorsig oor die tale wat oor die wêreld heen gebruik word. Hoofstukke vier tot sewe handel oor taalklassifikasie, die genealogiese indeling van Afrikaans, en dan, met 'n meer spesifiek wordende fokus, die verkenning van die IndoEuropese, Germaanse, en Wes-Germaanse taalfamilie. Hoofstukke 8-10 verken die Nederlandse taal, met spesifieke aandag aan die ontwikkeling van Nederlands sedert Oud-Nederlands, deur Middel- en Nieu-Nederlands, tot vandag met die taalsituasies in Nederland en België. Hoofstuk elf hanteer die ontstaan van Afrikaans, spesifiek die rol en omvang van taalverandering in die ontwikkeling van Afrikaans vanaf Nederlands. (Deel twee, wat binnekort verskyn, handel oor die vorming van Afrikaans in meer besonderhede, en die meer onlangse geskiedenis van Afrikaans.)

\section{Teikengroep}

Die boek is nie uitsluitlik op taalkundiges gemik nie - dit is toeganklik vir studente van Afrikaans asook ander wat die herkoms van Afrikaans in diepte wil verken. Die detail en omvang van die boek maak dit egter ook van waarde vir taalkundiges wat Afrikaans en ander tale bestudeer.

\section{Beoordeling}

Selfs slegs deel een van hierdie tweedelige studie is reeds van besondere omvang. Dit is duidelik dat die outeurs sover moontlik alle potensieel relevante onderwerpe (vir taalkundiges en ander lesers) aanroer, met aanbevole addisionele bronne indien 'n leser meer oor 'n spesifieke saak wil weet. Hoofstukke twee en drie kan verder nuttig wees as Afrikaanse bron vir studente van die algemene taalwetenskap.

Die diepte waarmee die genealogie van Nederlands, die verskillende fases in die ontwikkeling van Nederlands en die huidige konteks van die taal verken word, is veel meer as wat die fokus op slegs Afrikaans sou verg. Dit maak voorsiening vir diegene wat Nederlands en Afrikaans in verhouding tot mekaar wil bestudeer.

Daar is egter 'n paar punte van kritiek wat onder twee hooftemas saamgevat kan word. Die eerste is die gebruik van ideologies gelaaide terme en perspektiewe, sonder om alternatiewe te hanteer of die tersaaklike problematiek te verreken. Daar word byvoorbeeld deurlopend van 'volwaardige' tale gepraat, en 'beskaafde' tale en taalgebruik (teenoor 'plat' taalgebruik) - dit stel die Westerse perspektief op geskrewe standaardtale voorop (bv. verwysings na 'substandaard'), en skakel implisiet met koloniale idees van die beskaafdes teenoor die barbare. Daar word van 'basterterme' en 'basterwoorde' gepraat, wat op een plek gekontrasteer word met 'goeie inheemse terme' (bl. 291). Daar is ook heelwat tekens van essensialistiese konseptualiserings van taal en groepe mense: die band tussen taal en volk (bl. 89) en die onderskeid tussen volke (bl. 191); 'n taal wat 'n 'aard' en 'karakter' het (bl. 286, 326) en taalgebruik wat nie 'eg' is nie (bl. 312); die idee dat eiesoortige kennis en werklikheidsbeskouings in spesifieke tale opgesluit is (bl. 84, 90, 113). Die term 'volkstaal' word ook dikwels gebruik, soms met implisiet nasionalistiese uitbeeldings (bl. 273, 439). Taal word ook dikwels as 'n begrensde, self-vervatte, selfs lewende entiteit uitgebeeld: tale leef (bl. 89) en sterf (bl. 184), word bedreig (soos lewende spesies) (bl. 114), en het mag (bl. 111). Hierdie beeld word ook ondersteun deur van konsepte soos 'taalversteuring' teenoor 'normale' taalverandering te praat, wat impliseer dat die invloed van 'buite' abnormaal is. Heelwat van hierdie probleme rondom Afrikaans word in diepte in onder andere die proefskrif van Kriel (2013) hanteer. 
Die tweede onderwerp van my kritiek fokus op die navorsingsliteratuur oor die ontstaan en ontwikkeling (vroeër en later) van Afrikaans. Den Besten (2012:267) wys op die belangrike bydrae van vroeë taalkontak. Die handelsjargons van Engels-Khoikhoi en Nederlands-Khoikhoi wat sedert 1590 ontstaan het, het moontlik 'n invloed op die taalvorms gehad wat die Khoikhoin tydens (veral vroeë, maar ook latere) kontak met Nederlandse setlaars gebruik het. Die beginpunt vir die Afrika-geskiedenis van Afrikaans word egter deurlopend as 1652 gereken.

Die vestiging van 'n nuwe taalvorm, Afrikaans, word onomwonde as die laat agtiende eeu gereken. Studies van onder andere Deumert (2004) en Roberge (1994) het egter diepgaande implikasies vir die interpretasie van argivale data wat voorheen voorgehou is, asook die vroeë datering van die vestiging van Afrikaans. Die verskille tussen die spreektaal en die skryftaal was nie altyd so groot as wat navorsers voorheen aangeneem het nie, en daar was 'n linguistiese kontinuum van variëteite aan die Kaap eerder as diglossie met ' $n$ 'hoë' en 'lae' variëteit.

Daar word redelike sterk stellings gemaak oor die beperkte rol van kreolisering in die ontstaan van Afrikaans. Die standpunt en argumente van prominente kreoliste soos Mufwene (2008) dat kreooltale nie noodwendig uit pidgins ontwikkel het nie, word nie in ag geneem nie. Den Besten het ook heelwat werk oor moontlike pidgin-variëteite gedoen wat deur die Khoikhoin en die slawe gepraat is, indien die nodigheid van 'n pidgin-fase wel voorgehou word. Verder word daar van 'n lys kenmerke gebruik gemaak om 'n taal as 'n kreool (of nie) te klassifiseer, terwyl hierdie gebruik dikwels nie meer as sinvol aanvaar word nie (Kotzé 2001; Mufwene 2008:147). In Kotzé (2001) se hantering van die problematiek van kenmerklyste wys hy onder andere ook hoeveel die verskillende variëteite van Afrikaans in hierdie opsig verskil, iets wat aandag behoort te geniet indien daar wel op die gebruik van sulke lyste aangedring word.
Ten spyte van heelwat aandag aan die rol van die Christendom en die Bybel in die (Nederlandse en latere) geskiedenis van Afrikaans, word die rol van Islam en die gebruik van ArabiesAfrikaans in veral die negentiende eeu agterweë gelaat. Davids (1987:35) dui aan dat Moslems in die Kaap (Arabies) Afrikaans vir religieuse geskrifte en onderrig gebruik en daarin gepubliseer het verskeie dekades voordat Christene Afrikaans as skryftaal en onderrigtaal aangewend het. Dit is natuurlik moontlik dat hierdie onderwerp meer aandag in deel twee geniet, maar die eensydige seleksie in die beskrywing van die bydrae van religieuse gebruike in die ontwikkeling van Afrikaans is tog opvallend (veral aangesien die gebruik van Afrikaans as skryftaal vir so 'n belangrike funksie beklemtoon word).

\section{Ten slotte}

Die boek is omvattend en in baie opsigte besonder deeglik. Die samevoeging in een boek van soveel verwante onderwerpe, met die saambindende tema van die uiteindelike ontwikkeling van Afrikaans, sal vir baie lesers - taalkundiges, letterkundiges, en ander belangstellendes - van besondere waarde wees. Dit skep ook hoë verwagtings vir deel twee.

\section{Literatuurverwysings}

Davids, A., 1987, 'A view of the written Afrikaans of the Cape Muslims during the nineteenth and early twentieth centuries', South African Journal of Linguistics 5(1), 24-40. https://doi.org/10.1080/10118063.1987.9724243

Den Besten, H., 2012, 'From Khoekhoe foreigner talk via Hottentot Dutch to Afrikaans: The creation of a novel grammar', in T. van der Wouden (ed.), Roots of Afrikaans: Selected writings of Hans den Besten, pp. 257-287, John Benjamins, Amsterdam.

Deumert, A., 2004, Language standardization and language change: The dynamics of Cape Dutch, John Benjamins, Amsterdam. https://doi.org/10.1075/impact.19

Kotzé, E.F., 2001, 'Adjectival inflection in Afrikaans diachronics: An argument against the validity of creolization checklists', Journal of Germanic Linguistics 13(4), 381-391.

Kriel, M., 2013, 'Loose continuity: The post-apartheid Afrikaans Language Movement in historical perspective', PhD thesis, London School of Economics and Political Science.

Mufwene, S.S., 2008, Language evolution: Contact, competition and change, Continuum, London.

Roberge, P.T., 1994, 'On detecting a prior linguistic continuum in Cape Dutch', in G. Olivier \& A. Coetzee (reds.), Nuwe perspektiewe op die geskiedenis van Afrikaans: Opgedra aan Edith H. Raidt, pp. 153-165, Southern Boekuitgewers, Halfweghuis. 